\title{
The Analysis on Input and Process to K4 Achievement in Bondowoso District
}

\author{
Widya Choirun Nisak ${ }^{1}$, Ancah Caesarina Novi Marchianti ${ }^{1,2}$, Ristya Widi Endah Yani ${ }^{1,3}$ \\ ${ }^{1}$ Graduate Student, Magister Program of Public Health Education, Jember University, East Java (Indonesia), \\ ${ }^{2}$ Department of Public Health, Faculty of Medical Science, University of Jember, East Java (Indonesia), \\ ${ }^{3}$ Department of Public Health, Faculty of Dentistry, University of Jember, East Java (Indonesia)
}

\begin{abstract}
Introduction: K4 achievement was referred to a specific coverage of pregnant mother who have achieved to antenatal service which according to the standard, at least four times in a region during particular period of time. In Bondowoso District, the achievement of K4 was 82,7\%, thus, Bondowoso District has not fulfilled to the target plan achievement which has been established by East Java Government in about $88 \%$.
\end{abstract}

Objective: To analyze effects of input and process to the achievement of K4 in Bondowoso District.

Method: Quantitative research and cross sectional approach. The sample of research was taken from all midwifes who have implemented K4 achievement in Bondowoso District as many 190 midwifes. The data analysis was multiple linear regression. Findings: This research demonstrated to a significant effect between input and process to $\mathrm{K} 4$ achievement.

Conclusion: The variables of input (man, money, and materials) and process (organizing, actuating, and controlling) were factors which affected to the achievement of $\mathrm{K} 4$, therefore, it was suggested to the Office of Bondowoso District to concern more on the indicators of either input or process as knowledge on Human Resource, and facilities and infrastructures which were provided to the midwifes as the executor or implementer of K4 achievement.

Keywords: Input, Process, and K4 Achievement.

\section{Introduction}

The problem of health development in Indonesia was detected on the high rate of maternal mortality and infant mortality. Based on Khan's Low birth weight remains associated with key indicators not just of maternal poverty (notably adequate maternal education) but also markers of structural poverty in health care (notably

\section{Corresponding Author:}

Prof. Dr. Drg. Ristya Widi E.Y., M.Kes

Department of Public Health, Faculty of Dentistry, University of Jember, Jawa Timur (Indonesia)

Phone No. 085331990000

e-mail: ristya_widi@unej.ac.id quality $\mathrm{ANC})^{[6]}$. In Indonesia, this health problem was ranked on the second in Southeast Asia, specifically for the maternal mortality rate after Laos with the percentage 305 of 100 million in last 2015. A causal factor from this problem of maternal mortality rate was not maximal first screening and prevention attempt in the pregnancy complication during pregnancy test (ANC), particularly on K4 achievement which has not complied to the plan target 2017-2022. According to Department of Health of Republic Indonesia 2010, the pregnancy test (ANC) was a health service which given to pregnant mother during pregnancy period due to the established standard of pregnancy test service. The pregnancy test (ANC) could be exerted as the first screening to the baby condition. Based on the survey from Riskesdas 2018, the health service on pregnant mother in Indonesia has two indicators of SDGs which would be derived 
from the achievement of ANC, as K1 (ANC1) and $\mathrm{K} 4$ (ANC 4). K4 was the fourth or more contact of pregnant mother to the health officer to get pregnancy test service according to the standard, in minimum of four times of pregnancy test service with the frequency of once visit in first trimester (14 weeks), once visit in second trimester (in range of 14-28 weeks), and two times visit in third trimester (in range of 28-36 weeks) ${ }^{[12]}$. The achievement of K4 in Indonesia has not fulfilled to the plan target in $2018,2,1 \%$ from the target of strategic plan in 2018 $78 \%$, while the achievement of K4 in Indonesia has reached to $75,9 \%$ in 2019 . The achievement of K4 in East Java has reached $90,5 \%{ }^{[3]}$. In Bondowoso District, K4 achievement 83,5\%, therefore, Bondowoso District has not complied to the target of strategic plan which has been established by the Government of East Java in about $88 \%$. Bodowoso District has target of K4 strategic plan 95\%, and in fact, Bondowoso District has not fulfilled the strategic plan target as many $11,5 \%$ in 2018. From the total of 25 puskesmas in Bondowoso District, there were no one which could comply the achievement target of strategic plan K4 in Bondowoso district ${ }^{[4]}$.

The factor which could affect the success of strategic plan achievement of K4 was aspect of input, man (human resource). The variable of man which was referred by the researchers, the midwife who have implemented K4 achievement which considered from aspects of age, educational background, period of service, knowledge, and training ${ }^{[7]}$. Money or fund source (material) in this context was facilities and infrastructure as supporting tool and material availability which could be very influential to the success of $\mathrm{K} 4$ achievement program. Next, the process also has a significant role to follow up the input, thus, the process has some indicators which could affect this research, as organizing, actuating, and controlling. Besides those three indicators, another factor which could affect the research problem was environment which was influenced by level of education, occupation, social economic, and social characteristics of society which was influenced by family support, role of health officer, village apparatus support, public figure, and religious figure ${ }^{[12]}$.

This research aimed to analyze the effects of input and process to the achievement of $\mathrm{K} 4$ in Bondowoso District.

\section{Method}

This research exerted design of analytic observational and method of cross sectional approach. This research employed multivariate method in medium of SPSS 22. The population of this research was 190 midwifes who have practiced $\mathrm{K} 4$ achievement program in Bondowoso District. The technique of data sampling in this research was total sampling. The total sampling referred to a technique of data sampling where the total of sample was similar to the population ${ }^{[9]}$, therefore, the sample of research were all the midwifes who have implemented K4 achievement in Bondowoso District as many 190 midwifes. The variable of research was consisted of independent variable as input and process and dependent variable as $\mathrm{K} 4$ achievement. The instrument of data collection in this research was questionnaire. Next, the collected data would be analyzed through multiple linear regression method.

Research Findings: The result of analysis exerted multiple linear regression in this research would be presented into three sections, the first was respondent characteristic and the second was validity and reliability test, while the third one was analysis result.

\section{Respondent Characteristics:}

Table 1. Respondent Characteristics

\begin{tabular}{|l|l|c|c|}
\hline \multirow{2}{*}{ Respondent Characteristic } & \multirow{2}{*}{ Classification } & Total & Percentage \\
\cline { 3 - 4 } & & 34 & $17.89 \%$ \\
& $20-30$ years & 78 & $41.05 \%$ \\
Age & $31-40$ years & 56 & $29.47 \%$ \\
& $41-50$ years & 22 & $11.58 \%$ \\
& $51-60$ years & 190 & $100,00 \%$ \\
\hline
\end{tabular}




\begin{tabular}{|l|l|c|c|}
\hline \multirow{3}{*}{ Educational Background } & D III (Diploma) & 121 & $63,68 \%$ \\
& DIV/S1 (Bachelor) & 69 & $26,32 \%$ \\
& Total & 190 & $100,00 \%$ \\
\hline \multirow{5}{*}{ Service Period } & $<1$ Years & 34 & $17.89 \%$ \\
& $1-8$ Years & 55 & $28.95 \%$ \\
& $9-18$ Years & 46 & $24.21 \%$ \\
& $19-24$ Years & 32 & $16.84 \%$ \\
& $>24$ Years & 23 & $12.11 \%$ \\
& Total & 190 & $100.00 \%$ \\
\hline
\end{tabular}

Based on the table 1 above, it was identified that from 190 respondents, as many $63,68 \%$ or 121 respondents from the graduate of DIII (Diploma Program) and $26,32 \%$ or 69 graduates of $\mathrm{D} 4 / \mathrm{S} 1$ degree. The age of midwife in Bondowoso District who have implemented K4 achievement program, the respondents in age range $20-30$ years old $17,89 \%$, or approximately 34 respondents, age range $31-40$ years old $41,05 \%$ or approximately 78 respondents, age range 41-50 years old $29,47 \%$ or approximately 56 respondents, and age range $51-60$ years old $11,58 \%$ or approximately 22 respondents. The majority of respondents were the midwifes who have work experience along 1-8 years as many 55 midwifes or 28,95 .

Validity and Reliability Test: The validity test was aimed to clarify how great the validity and accuracy of an instrument to employ its function. To test the validity of research, the researchers used instrument of product moment pearson's correlation where they must correlate each statement to the total score, and then the correlation result was compared to the critical number $0,30^{[5]}$.

Whilst, the reliability test was aimed to test how far the result of measurement was relatively consistent. The good statement referred to a clear statement which was easily understood and has similar interpretation, although it was conveyed to the respondents in different way and different period of time. Further in this research, the reliability test was employed through Cronbach Alpha and this research instrument was considered as reliable, since it delivered to Cronbach Alpha value more than $0,60^{[8]}$.

Table 2. Validity and Reliability Test on Research Instrument

\begin{tabular}{|c|c|c|c|c|c|}
\hline No. & Item & $\mathbf{R}_{\text {cal }}$ & Explanation & Cronbach Alpha & Clarification \\
\hline \multirow{4}{*}{1} & (Man/Knowledge) X1.1 & 0,645 & Valid & \multirow{4}{*}{0,789} & Reliable \\
\hline & (Man/Training) X1.2 & 0,782 & Valid & & Reliable \\
\hline & (Money) X1.3 & 0,716 & Valid & & Reliable \\
\hline & (Materials) X1.4 & 0,733 & Valid & & Reliable \\
\hline \multirow{3}{*}{2} & Organizing (X2.1) & 0,822 & Valid & \multirow{3}{*}{0,724} & Reliable \\
\hline & (Actuacting) X2.2 & 0,787 & Valid & & Reliable \\
\hline & (Controlling) X2.3 & 0,798 & Valid & & Reliable \\
\hline 3 & Y & 0,783 & Valid & 0,737 & Reliable \\
\hline
\end{tabular}

Based on the table 2 above, it was referred that each indicator has $\mathrm{r}$ cal value which was greater than 0,30 . It indicated that the indicators which were used in this research variables were said as reliable or valid to collect the data. Moreover, the testing result showed that each variable has Cronbach Alpha value more than 0,60. Thus, it was concluded that all variables in this research were reliable. 


\section{Analysis Result}

a. T Test (Partial Hypothesis Test): The hypothesis of input and process in this research was tested its validity through partial test. This type of testing was aimed to see significant level (p-value), if the result of significance level from the calculation was fewer than 0,05 , then, the first hypothesis was approved, on the other hand, if the result of significance level was greater than 0,05 , thus, the hypothesis was disapproved.

According to the result of hypothesis testing on input variable, it was indicated that $t$ cal value 6,472 and significance level 0,021. This significance level was fewer than 0,05 , which referred that the variable of input has positive effect to the achievement of K4 in Bondowoso District. The variable of process indicated $t$ cal value 9,346 and significance level 0,013 . This significance level was fewer than 0,05 , which referred that it has positive effect to the achievement of K4 in Bondowoso District.

b. F Test (Simultaneous Hypothesis Test): To test the independent variable simultaneously, the researchers tested through $F$ test.. Next, the result of statistic calculation who wed that $\mathrm{F}$ cal value $=$ 153,474. By exerting the significance level 0,05 , it was derived that the significance level was fewer than 0,05 . It referred that the hypothesis has stated that the variable of input and process have effects simultaneously to the achievement of $\mathrm{K} 4$ in Bondowoso District.

c. Determinant Coefficient (R): The determinant coefficient was a scale which indicated the variation size of dependent variable which could be explained by the independent variable. The value of determinant coefficient was determined by the value of adjusted $\mathrm{R}$ square.

The result of regression calculation showed that the determinant coefficient (adjusted R2) 0,792 or $79,2 \%$, which referred that the variable variation of K4 achievement in Bondowoso District could be explained by the variable of input and process. While, the rest $20,8 \%$ was explained by other variables which were not submitted in this research.

\section{Discussions}

Based on the research finding, it showed that the majority of midwifes as the implementers of $\mathrm{K} 4$ achievement program have age, educational level, and service period which were categorized into stable and consistent stage of career development, besides, the indicators as input (man, money, and materials) and process (organizing, actuating, and controlling) have positive effects to the achievement of $\mathrm{K} 4^{[1]}$. K4 achievement was referred as a form of assessment on the level of health development which must be implemented by Health Office of Bondowoso District as an attempt to improve $\mathrm{K} 4$ program achievement through visit service ANC 1 (K1) and visit ANC 4 which was optimally according to the minimum standard of service. The indicators of $\mathrm{K} 4$ achievement was the implementation of ANC 4 (the fourth pregnancy test by health officer). Moreover, the continuous treatment must be conducted by identifying the variable of input (man, money, and materials) and process (organizing, actuating, and controlling) which was executed by the service provider in order to realize the achievement of $\mathrm{K} 4$ which complied the strategic plan target in about $95 \%{ }^{[11]}$.

This research finding was in line with the theory stated by Tampubolon, the implementation of health program was not apart from its health management system, as input, process, and output. The administration input was valued as all things that were needed to implement administration task ${ }^{[10]}$. Within this input, it required to management unsure: 4M (Man, Money, Material, and Method ${ }^{[2]}$. Next, process was referred as steps which must be taken to achieve goals. According to G,R Terry in Satrianegara (2014), there are four functions of administration in the process, but the researchers only employed three functions of administration in this research, as organizing, actuating, and controlling ${ }^{[1]}$. The organizing step was identified from the availability of implementer or midwife and organizational structure who perform $\mathrm{K} 4$ achievement. Actuating was seen from the implementation of $\mathrm{K} 4$ visit according to the standard operational of implementation.

The research done by Sulistiyani (2016) has supported to this research finding that the evaluation of implementation of $\mathrm{K} 4$ achievement service in Puskesmas Jakenan was due to the system approach and covered to human resource, thus, the implementation of $\mathrm{K} 4$ achievement service was less and output was not achieved ${ }^{[12]}$. Moreover, the research done by Titiwiarti 2013 has also demonstrated that the scope of antenatal visit (K4) was caused by lack of facilities and infrastructures, fund availability which has not fulfilled to the service need, not maximal recording and reporting which caused to not optimal visit achievement ${ }^{[14]}$. 
Based on the result of statistic testing, it was clearly identified that the independent variables were related to the dependent variable. The relation which given by the independent variables was positive, which referred that the relation of both variables was in the same direction. Therefore, the relation was positive as long as the independent variables were increased, the dependent variable would also increase as well. in short, the better variable of input and process would affect to the higher achievement of K4 program in Bondowoso District.

Next, the main problems which could emerge during the implementation of $\mathrm{K} 4$ in Bondowoso district was the limited resource, from either the aspect of facility and infrastructure or funding that have been established by Puskesmas or Health Office of Bondowoso District. Moreover, the geographical aspect of Bondowoso District where was surrounded by hills was also the problem for the health officer or midwife to conduct socialization concerning to K4 achievement. Further, the signal trouble of difficulty which was experienced by midwife who was on duty in the suburbs of district, for instance Sub-district of Ijen, Tlogosari, Wringin, and Tamankrocok.

It was also suggested to the Health Office of Bondowoso District to conduct monitoring and evaluation to the implementation of $\mathrm{K} 4$ in suburbs of district, in order to get the problems of health officer including to the provision of facility and infrastructure which functioned to support the health officer to provide service. In addition, it also needed to some trainings in continuous by the officer of $\mathrm{K} 4$, especially in particular regions which did not comply the strategic plan target of Health Officer of Bondowoso District and Government of East Java.

\section{Conclusions}

Based on the result of data analysis, this research showed that the variable of input (man, money, and materials) and process (organizing, actuating, and controlling) affected positively and significantly to the achievement of K4 in Bondowoso District. However, based on the report of $\mathrm{K} 4$ achievement in Bondowoso District, it has not fulfilled yet to the strategic plan target in the district level or East Java Province. Although, all inputs and processes have obeyed to the standard operational of service according to Permenkes 97. This condition was not referred to bad capability of human resource to serve the clients according to the standard operational, but there were some external factors that could affect to $\mathrm{K} 4$ achievement, so it could not fulfill yet to the target of strategic plan. The external factor was geographical problem which was mostly found by the health officer or midwife in suburbs as well as mountain area in Bondowoso District. Moreover, the limited access of signal or network in some regions might also cause to the lateness on process of information reception and submission of activity report.

\section{Conflict of Interest: Nothing}

\section{Source of Funding: Self}

Ethical Clearance: This research has undergone ethical test in ethics commission of health research of Faculty of Dentistry, University of Jember in this following registration number 354/UN25.8/KEPK/ DL/2019.

\section{References}

1. Athoillah. Dasar-Dasar Manajemen. Bandung: CV Pustaka Setia. 2010. p. 110-111.

2. Azwar. Pengantar Administrasi Kesehatan Edisi Ketiga. Jakarta: Binarupa Aksara Publisher. 2010. p. 22.

3. Dinkes Jatim. Profil Kesehatan Profinsi Jawa Timur [Internet].2016.[Diakses 08 Juni2018].http://dinkes. jatimprov.go.id/userimage/PPTKESEHATAN\%20 JATIM\%DALAM20\%ANGKA\%20.html

4. Dinkes Kabupaten Bondowoso. Profil Kabupaten Bondowoso [Internet]. 2017. [Diakses 10 Juni 2018]. http://www.depkes.go.id/resources/download/ profil/PROFIL_KAB_KOTA_2016/3511_Jatim_ Kab_Bondowoso_2016.pdf

5. Ghozali, Imam. AplikasiAnalisis Multivariate dengan SPSS. Semarang: Badan Penerbit UNDIP. 2005. p. 82-83.

6. Khan. 2018. Analysis of Low Birth Weight And It's Co-Variants In Bangladesh Based On A SubSampel From Nationally Respresentative Survey. Journal. 18(100):7-9

7. Notoadmodjo. Pengembangan Sumber Daya Manusia. Jakarta: Rineka Cipta. 2009. p. 124.

8. Sugiyono. Metodelogi Penelitain Kuantitatif. Bandung: Alfabeta. 2018. p. 15. 
9. Sugiyono. Metodelogi Penelitain Kuantitatif. Bandung: Alfabeta. 2018. p. 15.

10. Satrianegara. Organisasi dan Manajemen Pelayanan Kesehatan: Teori dan Aplikasidalam Pelayanan Puskesmas dan RumahSakit. Jakarta: Salemba Medika. 2014. p. 109.

11. Satrianegara. Organisasi dan Manajemen Pelayanan Kesehatan: Teori dan Aplikasidalam Pelayanan Puskesmas dan Rumah Sakit. Jakarta: Salemba Medika. 2014. p. 109.
12. Sulistiyani. 2016. Evaluasi Pelaksanaan Pelayanan Cakupan K4 Di Puskesmas Jakenan Pati.Jurnal. 4(1):30-33.

13. Tando, Naomy. Organisasi dan Manajemen Pelayanan Kesehatan. Jakarta: In Media. 2013. p. 11-13.

14. Titiwiarti. 2016. Studi Tentang Pengelolaan Program Pelayanan Antenatal CareDi Puskesmas Pasarwajo Kabupaten Buton Tahun 2017. Jurnal. 3(1):3-8. 